\title{
IPTEKS PERHITUNGAN POTENSI PENERIMAAN PAJAK HOTEL TERHADAP PENDAPATAN ASLI DAERAH DI KABUPATEN MINAHASA UTARA
}

\author{
Pongtuluran Andri Christian \\ Jurusan Akuntansi, Fakultas Ekonomi dan Bisnis, Universitas Sam Ratulangi, Jl. Kampus Bahu, Manado, \\ 95115, Indonesia \\ E-mail : andripongtuluran46@gmail.com
}

\begin{abstract}
The implementation of autonomy for the local government drive the efforts to explore their own financial resources and potential tax revenue. The local government has authority, rights and obligation to manage finance, infrastructure and human resource. It is important for local government to find out the tax potency to set a revenue target for next period, as a part of government planning. The method used is calculating the potential of hotel tax revenues to Local Own Source Revenue (PAD) in North Minahasa Regency. The technique applied is calculating the increase in the realization of potential hotel taxes each year and the average rate of increase in hotel tax potential. After calculate the Increase in Realization of Each Year, and the average rate of increase, the result of potential hotel tax in North Minahasa Regency. is Rp. 3,285,398,969,531.2. at 2016.
\end{abstract}

Keywords : Autonomy, Hotel tax, Tax realization, Tax potency

\section{PENDAHULUAN}

Tuntutan peningkatan Pendapatan Asli Daerah (PAD) semakin tinggi karena semakin Banyak wewenang yang dilimpahkan pemerintah pusat kepada pemerintah daerah. Peningkatan PAD merupakan indikator keberhasilan pengelolaan keuangan daerah. Transfer keuangan yang dilakukan pemerintah pusat harus diikuti dengan kreatifitas pemerintah daerah dalam menggali potensi yang dimiliki daerah (Uman, 2014).

Pendapatan Asli Daerah mencerminkan tingkat kemandirian suatu daerah, jika pendapatan daerah tinggi maka semakin tinggi pula kemandirian suatu daerah (Baskara, Saifi dan Zahro, 2018). Pemerintah daerah dapat meningkatkan PAD dengan menggali potensipotensi yang ada di daerah. Salah satu sumber PAD adalah pajak daerah. Pajak daerah memiliki kontribusi penting dalam proses pembangunan karena pajak daerah merupakan sumber pendapatan bagi suatu daerah (Ardhiansyah, Rahayu dan Husaini, 2014), dan berfungsi sebagai dana bagi pemerintah untuk membiayai pengeluaran-pengeluarannya (Mardiasmo, 2016:1). Pajak hotel merupakan pajak daerah yang saat ini potensinya semakin berkembang seiring dengan berkembangnya sektor jasa dan pariwisata serta berkembangnya bisnis rekreasi. Pariwisata memberikan sumbangan terhadap pendapatan daerah (Sugiarto, Danurdara, dan Rofi, 2015), karena itu perlu dilakukan identifikasi terhadap potensi pariwisata yang berdampak terhadap pendapatan daerah. Beberapa tahun terakhir, Sulawesi Utara banyak kedatangan turis asing dan bahkan jumlahnya terus bertambah seiring di tetapkannya penerbangan langsung dari Sulawesi Utara ke China maupun sebaliknya. Berdasarkan data Badan Pusat Statistik Jumlah wisatawan mancanegara yang datang ke Sulawesi Utara dan tingkat hunian hotel meningkat setiap tahun 
Tabel 1

\begin{tabular}{lccc}
\hline & Tahun 2014 & Tahun 2015 & Tahun 2016 \\
\hline Jumlah wisatawan mancanegara & 17279 & 19465 & 40624 \\
Tingkat hunian hotel : & & & \\
-Januari & 43.93 & 31.36 & 63.02 \\
-Februari & 43.73 & 45.95 & 64.90 \\
-Maret & 55.46 & 51.50 & 65.58 \\
-April & 46.84 & 55.72 & 62.70 \\
-Mei & 55.16 & 56.15 & 64.32 \\
-Juni & 55.99 & 56.58 & 58.73 \\
-Juli & 50.75 & 56.60 & 59.23 \\
-Agustus & 54.17 & 58.91 & 68.86 \\
-September & 57.46 & 59.49 & 67.89 \\
-Oktober & 53.47 & 59.86 & 68.37 \\
-November & 58.09 & 62.54 & 72.69 \\
-Desember & 46.51 & 64.56 & 63.38
\end{tabular}

Guna menopang eksistensi otonomi daerah yang maju, sejahtera, mandiri dan berkeadilan, Kabupaten Minahasa Utara dihadapkan pada suatu tantangan dalam mempersiapkan strategi dalam perencanaan pembangunan yang akan diambil. Untuk itu diperlukan suatu perencanaan yang tepat dengan memperhatikan potensi yang dimilikinya Pemerintah daerah Kabupaten Minahasa dan Kabupaten Minahasa Utara perlu melakukan penghitungan potensi pajak daerah, karena berdasarkan perhitungan potensi pajak akan ditentukan target penerimaan pajak pada periode berikutnya dengan tepat

\section{TINJAUAN PUSTAKA}

\subsection{Pajak Daerah}

Pajak daerah merupakan salah satu jenis pengelompokkan pajak menurut lembaga pemungutnya. Pajak daerah dipungut daerah berdasarkan undang-undang dan digunakan untuk membiayai kegiatan pemerintah daerah. Definisi pajak daerah menurut UndangUndang Nomor 34 tahun 2000 pasal 1 ayat 6 adalah "iuran wajib yang dilakukan oleh orang pribadi atau badan kepada daerah tanpa imbalan langsung yang seimbang, yang dapat dipaksakan berdasarkan peraturan perundang-undangan yang berlaku, yang digunakan untuk membiayai penyelenggaraan Pemerintah Daerah dan Pembangunan Daerah".

Peraturan Pemerintah Republik Indonesia Nomor 55 tahun 2016 tentang ketentuan umum dan tata cara pemungutan pajak daerah dan Undang-Undang Republik Indonesia Nomor 28 Tahun 2009 Tentang Pajak Daerah dan Retribusi Daerah mengelompokkan jenis pajak atas 1) pajak provinsi, 2) pajak kabupaten. Daerah dapat memungut salah satu atau beberapa jenis pajak yang telah ditetapkan atau dapat juga memungut jenis pajak daerah yang lain.

Pajak Hotel adalah Jenis Pajak kabupaten/kota yang dibayar sendiri berdasarkan penghitungan oleh Wajib Pajak. Pajak Hotel adalah Pendapatan Asli Daerah Dalam Otonomi Daerah. Objek pajak daerah Kabupaten/ Kota sesuai Undang-undang nomor 1 tahun 2011 tentang Pajak Hotel adalah pelayanan yang disediakan hotel dengan pembayaran termasuk fasilitas penginapan, pelayanan penunjang, fasilitas oleh raga dan hiburan dan jasa persewaan ruangan untuk kegiatan.

Potensi pajak adalah hasil temuan pendataan di lapangan terkait jumlah serta frekuensi objek pajak yang kemudian dikalikan dengan tarif dasar pajak. Potensi pajak menentukan besarnya pajak yang akan dipungut oleh daerah, sehingga dapat ditetapkan target 
penerimaan pajak pada satu periode. Target penerimaan pajak daerah dapat membantu perencanaan dan pengendalian pelaksanaan pemungutan pajak (Prasetya, 2016).

\subsection{Pendapatan Asli Daerah}

Undang-Undang Nomor 33 Tahun 2004 tentang Perimbangan Keuangan Antara Pusat dan Daerah mendefinisikan "Pendapatan Asli Daerah adalah pendapatan yang diperoleh daerah yang dipungut berdasarkan peraturan daerah sesuai dengan peraturan perundang undangan". Sumber-sumber PAD adalah 1) pajak daerah, 2) hasil retribusi daerah, 3) basil pengelolaan kekayaan daerah yang dipisahkan, dan lain-lain pendapatan asli daerah yang sah.

Pemberian hak dan wewenang bagi pemerintah daerah untuk mengatur dan mengurus urusan pemerintahan dimaksudkan untuk meningkatkan kesejahteraan masyarakat, pelayanan umum, dan daya saing daerah. Undang-Undang Republik Indonesia Nomor 32 Tahun 2004 Tentang Pemerintahan Daerah menjabarkan tentang otonomi daerah dalam hal pemberian hak, wewenang dan kewajiban. Otonomi ini merupakan dorongan bagi pemerintah daerah untuk meningkatkan potensi-potensi sumber pendapatan. Peningkatan pendapatan daerah akan menjadikan pemerintah daerah mandiri dan tidak bergantung pada dana perimbangan dari pemerintah pusat.

Otonomi daerah memberikan peluang bagi pemerintah daerah untuk meningkatkan potensi-potensi daerah sehingga mampu membiayai pengeluaran-pengeluaran pemerintah, mensejahterakan masyarakat dan meningkatkan daya saing daerah. Pemerintah daerah yang mampu mengelola otonomi daerah dapat dilihat pada keberhasilan pengelolaan keuangan daerah. Kemandirian suatu daerah tergantung pada upaya pemerintah daerah menggali sumber keuangan sendiri dan meminimalkan tingkat ketergantungan keuangan daerah pada pemerintah pusat.

\section{METODE DAN TEKNIK PENERAPAN IPTEKS}

\subsection{Metode Penerapan Ipteks}

Metode penerapan ipteks yang digunakan adalah menghitung potensi penerimaan pajak hotel terhadap Pendapatan Asli Daerah (PAD) di Kabupaten Minahasa Utara.

\subsection{Teknik Penerapan Ipteks}

Teknik yang diterapkan adalah menghitung kenaikan realisasi potensi pajak hotel tiap tahun pajak dan rata-rata tingkat kenaikan potensi pajak hotel

\section{PEMBAHASAN}

\subsection{Gambaran Objek Penerapan Ipteks}

Kabupaten Minahasa Utara (sering disingkat Minut) adalah salah satu kabupaten di Sulawesi Utara, Indonesia, dengan pusat pemerintahan dan ibukota di Airmadidi. Kabupaten ini memiliki lokasi yang strategis karena berada di antara dua kota, yaitu Manadi dan kota pelabuhan Bitung, dengan jarak dari pusat kota Manado ke Airmadidi sekitar $12 \mathrm{~km}$ yang dapat ditempuh dalam waktu 30 menit. Sebagian dari Kawasan Bandar Udara Sam Ratulangi terletak di wilayah Minahasa Utara.

Kabupaten ini dibentuk berdasarkan Undang-Undang Nomor 33 Tanggal 18 Desember 2003, tentang Pembentukan Kabupaten Minahasa Utara di Provinsi Sulawesi Utara dan Diresmikan Mendagri atas nama Presiden Republik Indonesia pada tanggal 07 Januari 2004. Kabupaten ini memiliki luas wilayah sekitar $2.314,39 \mathrm{~km} 2$ dengan rincian luas darat mencapai 1.053,39 km2 dan luas laut $1.261 \mathrm{~km} 2$. Jumlah Penduduk dari hasil registrasi pada tahun 2015, yaitu sebesar 196.419 jiwa dengan kepadatan penduduk mencapai 187,01 per km2. Penduduk Kabupaten Minahasa Utara sebagian besar adalah etnis Minahasa Tonsea. Kabupaten Minahasa Utara saat ini terdiri dari 10 Kecamatan, 125 desa dan 6 kelurahan. 


\subsection{Pembahasan}

Analisis perhitungan potensi diperlukan dalam analisis menetapkan target rasional. Dengan potensi yang ada, setelah dibandingkan penerimaan untuk masa yang akan datang maka akan didapatnya besar potensi yang terpendam, sehingga akan dapat diperkirakan rencana dan tindakan apa yang akan dilakukan untuk menggali potensi yang terpendam untuk menentukan berapa besarnya rencana penerimaan yang akan datang.

Tabel 2

Data Realisasi Penerimaan Pajak Hotel Kabupaten Minahasa Utara

\begin{tabular}{ccc}
\hline No & Tahun Anggaran & Realisasi \\
\hline 1 & 2011 & 5.273 .721 .498 \\
2 & 2012 & 10.710 .695 .408 \\
3 & 2013 & 11.256 .793 .033 \\
4 & 2014 & 20.070 .101 .061 \\
5 & 2015 & 25.266 .469 .042 \\
\hline
\end{tabular}

Sumber: Dinas Pendapatan Pengelolaan Keuangan dan Aset Daerah

\section{Menghitung Kenaikan Realisasi Tiap Tahun}

1) Tahun $2011 / 2012=\frac{10.710 .695 .408-5.273 .721 .498}{10.710 .695 .408} x 100 \%=50,77 \%$

2) Tahun $2012 / 2013=\frac{11.256 .793 .033-10.710 .695 .408}{11.256 .793 .033} x 100 \%=4,86 \%$

3) Tahun $2013 / 2014=\frac{20.070 \cdot 101 \cdot 061-11.256 .793 .033}{20.070 .101 .061} x 100 \%=43,92 \%$

4) Tahun $2014 / 2015=\frac{25 \cdot 266.469 .042-20.070 .101 .061}{25.266 .469 .042} \times 100 \%=20,57 \%$

Tabel 3

Persentase Kenaikan Penerimaan Pajak Hotel Kabupaten Minahasa Utara Tahun Anggaran 2011-2015

\begin{tabular}{ccc}
\hline No & Tahun Anggaran & Persentasi Kenaikan $(\%)$ \\
\hline 1 & $2011-2012$ & $50,77 \%$ \\
2 & $2012-2013$ & $4,86 \%$ \\
3 & $2013-2014$ & $43,92 \%$ \\
4 & $2014-2015$ & $20,57 \%$ \\
\hline
\end{tabular}

Sumber : Data Diolah 2017

Hasil perhitungan menunjukkan bahwa realisasi penerimaan pajak hotel terjadi kenaikan sebesar 50,77\% pada tahun 2012, tahun 2013 mengalami penurunan sebesar 4,86\%, pada tahun 2014 mengalami peningkatan sebesar 43,92 dan pada tahun 2015 mengalami penurunan sebesar $20,57 \%$. 
2. Menghitung Rata-rata Tingkat Kenaikan

$$
\mathrm{Xt}=\frac{50,7 \%+4,86 \%+43,92 \%+20,57 \%}{4}=30,03 \%
$$

\section{Menghitung Potensi Pajak Hotel Tahun 2016}

$2016=(100 \%+30,03 \%) \times 25.266 .469 .042=3.285 .398 .969 .531,2$

Setelah menghitung kenaikan realisasi tiap tahun dan rata-rata tingkat kenaikan tiap tahun, maka dapat diketahui jumlah potensi penerimaan Pajak Hotel Kabupaten Minahasa Utara tahun 2016 sebesar Rp 3.285.398.969.531,2.

Berdasarkan perhitungan dapat dilihat bahwa realisasi penerimaan pajak hotel terjadi kenaikan sebesar 50,77\% pada tahun 2012, tahun 2013 mengalami penurunan sebesar 4,86\%, pada tahun 2014 mengalami peningkatan sebesar 43,92 dan pada tahun 2015 mengalami penurunan sebesar $20,57 \%$.

Selanjutnya untuk mengetahui rata-rata tingkat kenaikan potensi pajak hotel dapat dihitung dengan cara menjumlahkan seluruh realisasi potensi dari tahun 2011 sampai dengan 2015 lalu dibagi sesuai dengan tahun anggaran yang diteliti.

Kemudian untuk menghitung potensi pajak hotel pada tahun 2016 dapat di lakukan dengan cara menjumlahkan total rata-rata tingkat kenaikan potensi pajak hotel dengan seratus persen, lalu dikalikan dengan total realisasi anggaran pada tahun 2015.

Dengan melihat presentase potensi yang diberikan pajak hotel terhadap Pendapatan Asli Daerah Kabupaten Minahasa Utara dapat disimpulkan bahwa kenaikan realisasi potensi tiap tahun selama kurun waktu 2011-2015 sebesar 30,03\%, dan potensi penerimaan pajak Hotel pada tahun 2016 akan mengalami kenaikan.

\section{KESIMPULAN DAN SARAN}

\subsection{Kesimpulan}

Ipteks penghitungan potensi pajak hotel terhadap pendapatan asli daerah di Kabupaten Minahasa Utara periode anggaran tahun 2011 sampai 2015, bertujuan untuk menentukan potensi pajak hotel tahun 2016. Penghitungan potensi dilakukan dengan Menghitung Kenaikan Realisasi Tiap Tahun, kemudian menghitung rata-rata tingkat kenaikan, selanjutnya menghitung potensi pajak hotel di Kabupaten Minahasa Utara. Potensi pajak hotel di Kabupaten Minahasa Utara adalah Rp 3.285.398.969.531,2.

\subsection{Saran}

Pemerintah daerah berupaya menggali potensi dan kebutuhan masyarakat didaerah dan sekaligus memberikan jenis-jenis pelayanan publik yang dibutuhkan oleh masyarakat di daerah, dengan demikian akan terjadi peningkatan penerimaan pajak.

\section{DAFTAR PUSTAKA}

Ardhiansyah, D., Rahayu, S. M., dan Husaini. 2014. Analisis Potensi Pajak Hotel dan Pajak Restoran dan Kontribusinya terhadap Pendapatan Asli Daerah (PAD). Jurnal Administrasibisnis (JAB), 14(1), 1-8.

Baskara, A., Saifi, M., dan Zahro, ZA. 2018. Evaluasi Tingkat Efektivitas Dan Pertumbuhan Penerimaan Pajak Restoran Terhadap Pajak Daerah. Jurnal Administrasi Bisnis, 56(1), 2-37.

Mardiaso. 2016. Perpajakan Edisi Terbaru. Penerbit Andi. 
Peraturan Pemerintah Republik Indonesia Nomor 55 Tahun 2016 Tentang Ketentuan Umum dan Tata Cara Pemungutan Pajak Daerah.

Prasetya, W. P. 2016. Potensi Pajak Hotel dan Pajak Restoran di Kota Bandar Lampung. Tesis Program Magister Ilmu Akuntansi, Fakultas Ekonomi dan Bisnis Universitas Bandar Lampung.

Sugiarto, Y., Danurdara, A, B, dan Rofi, N. 2015. Analisis Potensi Penerimaan Pajak Hotel di Kabupaten Pemalang Jawa Tengah. Barista, 2(1), 47-61.

Umam, I. K. 2014. Potensi Pendapatan Asli Daerah Dalam Rangka Pelaksanan Otonomi Daerah di Kabupaten Indramayu. Salam Jurnal Filsafat dan Budaya Hukum 1(2), 330340.

Undang-Undang Nomor 33 Tahun 2004 tentang Perimbangan Keuangan Antara Pusat dan Daerah .

Undang-Undang Republik Indonesia Nomor 28 Tahun 2009 Tentang Pajak Daerah dan Retribusi Daerah

Undang-Undang Republik Indonesia Nomor 32 Tahun 2004 Tentang Pemerintahan Daerah

Undang-Undang Nomor 34 tahun 2000 tentang Perubahan Atas Undang-Undang Republik Indonesia Nomor 1 tahun 1997 tentang Pajak Daerah dan Retribusi Daerah.

Undang-Undang nomor 1 tahun 2011 tentang Pajak Hotel, Un dang-undang nomor 2 tahun 2011 tentang Pajak Restoran 